\title{
Numerical modeling of a hydrocyclone in the system of technical water supply under the conditions of the UAE
}

\author{
S. Surkov ${ }^{\text {I }}{ }^{\text {Hussam } \text { Ghanem }^{2} \text {, V. Kravchenko }}{ }^{3}$ \\ ${ }^{1,2,3}$ Odessa National Polytechnic University, 1 Shevchenko Ave., Odessa, 65044, Ukraine \\ $\triangle$ e-mail:: ${ }^{1}$ ssv@opu.ua \\ ORCID: ${ }^{1}$ https://orcid.org/0000-0002-3112-3041; ${ }^{2}$ https://orcid.org/0000-0002-2416-198X; \\ ${ }^{3}$ https://orcid.org/0000-0002-7557-3327
}

\begin{abstract}
The article is devoted to solving a practical problem: the choice of equipment for pre-treatment of salt water that feeds the desalination plant. The preliminary stage of desalination is the purification of water from sand particles, which can significantly reduce productivity and even damage the desalination plant, which is situated at the next stage. For pre-treatment, settling tanks, hydrocyclones, sand filters, etc. are used. The main dimensions of hydrocyclones of standard designs are calculated based on well-known recommendations. Modern computer simulation systems allow you to create three-dimensional models of the apparatus being studied, and then calculate the velocity and pressure fields in them. It was necessary to estimate the amount of sand contained in the feed water. To solve this problem, an experimental hydrocyclone was developed and manufactured. The hydrocyclone was numerically simulated and the sand capture coefficient was estimated under various operating conditions. It has been established that an experimental hydrocyclone reliably captures grains of sand 50 microns in size and above. The average daily mass of trapped sand was experimentally determined. Numerical modeling made it possible with reasonable accuracy to estimate the sand capture coefficient by an experimental hydrocyclone. During the tests, the mass of sand entering the pipeline per day was determined. The hydrocyclone reliably captures sand particles of 50 microns or more. At the same time, a significant part of particles less than 50 microns is not captured by the hydrocyclone, which is why a sand filter was chosen for industrial use. In the future, it is advisable to use a serial connection of a hydrocyclone and a sand filter, but such a solution requires additional technical and economic calculation. It is concluded that in the case under consideration, it is advisable to use a sand filter for preliminary water treatment.
\end{abstract}

Key words: Numerical modeling; Hydrocyclone; System of technical water supply; Sand filters; Preliminary water treatment

\section{doi: https://doi.org/10.15673/ret.v55i4.1636}

\section{Introduction}

One of the main problems of the oil-rich state of the UAE is the lack of fresh water. In the desert in the emirate of Abu Dhabi, there are small salt lakes. Groundwater there is also salty [1].

For technical water supply to the labor camp and ornamental plant nursery of Citiscape LLC, it was decided to desalinate water from a nearby lake using a reverse osmosis unit.

The problem is, that a significant amount of sand gets into the lake during frequent sandstorms in the region. Additional pollution can be brought by the flamingos inhabited nearby. Thus, there is a need for 
preliminary cleaning of salt water from sand and other particles.

However, to select the treatment equipment, it was necessary to evaluate the actual sand content in the water. To solve this problem, it was decided to build an experimental hydrocyclone, having previously determined its characteristics by numerical simulation.

\section{Literature Review}

The preliminary stage of desalination is the purification of water from sand particles, which can significantly reduce productivity and even damage the desalination plant, which is situated at the next stage. For pre-treatment, settling tanks, hydrocyclones, sand filters, etc. are used [2, 3].

The main dimensions of hydrocyclones of standard designs are calculated based on well-known recommendations [4, 5]. However, in our case, a simplified design hydrocyclone was used, which necessitated the numerical simulation.

Modern computer simulation systems allow you to create three-dimensional models of the apparatus being studied, and then calculate the velocity and pressure fields in them [6]. An additional task is to study the motion of a solid particle described by a system of ordinary differential equations, which in vector form takes the form [7]

$$
m \frac{d^{2} \vec{r}}{d t^{2}}=\vec{F}-c_{f} A \frac{\rho \mid \vec{v}_{\text {отн }} \vec{v}_{\text {отн }}}{2}
$$

where $m$ - the particle mass, $\mathrm{kg}$;

$$
\vec{r}(x, y, z) \text { - radius vector determining the posi- }
$$

tion of the particle;

$\vec{F}$ - the vector of mass forces, $\mathrm{N}$;

$c_{f}$ - drag coefficient of the particle;

$A-$ the area of the mid-section of the particle, $\mathrm{m}^{2}$; $\rho$ - water density, $\mathrm{kg} / \mathrm{m}^{3}$.

As a first approximation, a particle in usually assumed ho have the spherical shape, and only gravity is taken into account from mass forces. Given the geometry of the ball, equation (1) can be rewritten in the form

$$
\frac{d^{2} \vec{r}}{d t^{2}}=\vec{g}-\frac{3}{2} \frac{\rho c_{f}}{\rho_{\mathrm{Y}} d_{\mathrm{Y}}} \frac{\left|\vec{v}_{\text {отн }}\right| \vec{v}_{\text {отн }}}{2},
$$

where $g$-vector of gravity acceleration, $\mathrm{m} / \mathrm{s}^{2}$;

$\rho_{\text {ч }}$ - particle density, $\mathrm{kg} / \mathrm{m}^{3}$;

$d_{\mathrm{u}}$ - particle diameter, $\mathrm{m}$.

The sufficiently large number of particles "launched" into the apparatus, makes it possible to obtain the statistical characteristics of a two-phase flow, in particular, estimate the particle capture coefficient in a hydrocyclone.

\section{Description of the experimental setup}

To simplify the design, the cyclone body was made of 4-inch steel pipe, and for the inner pipe, 2inch pipe. The general view of the experimental hydrocyclone as part of the desalination plant is shown in Figure 1.
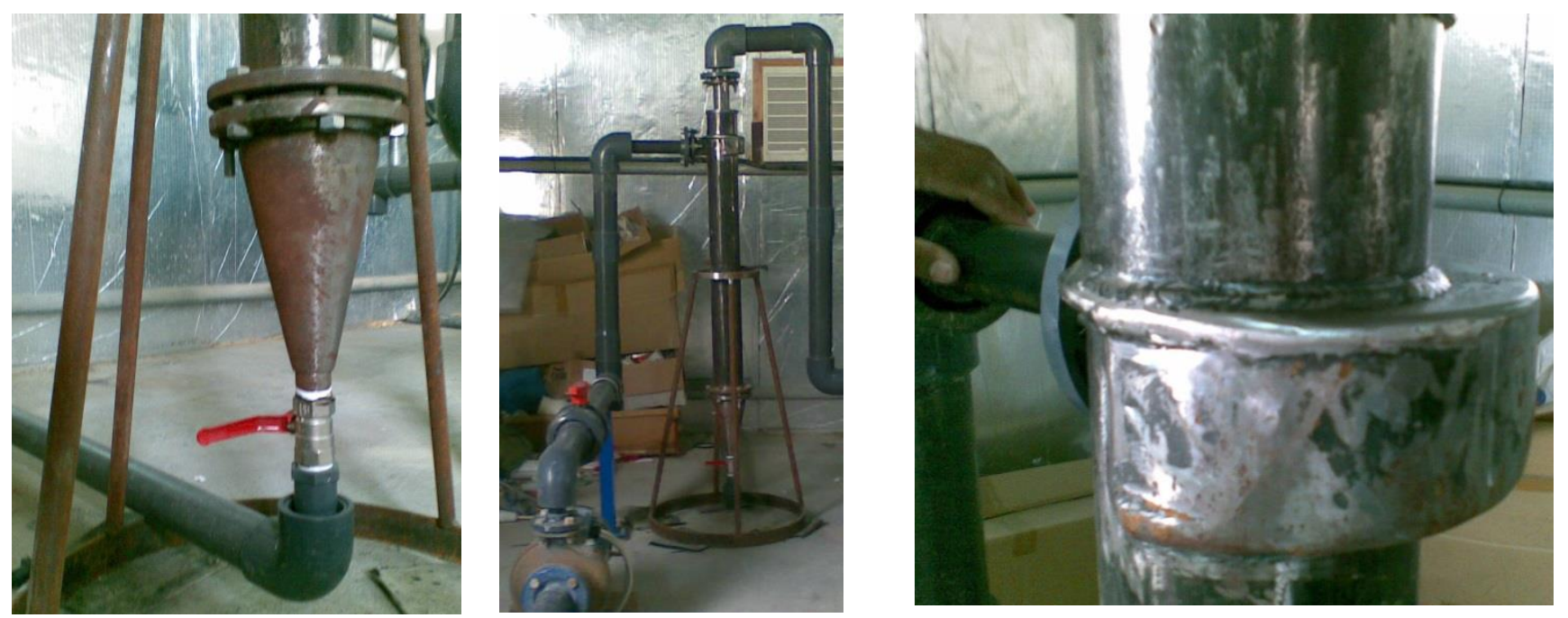

Figure 1 - Experimental hydrocyclone

In the upper part of the hydrocyclone, a water supply in the form of a snail was formed. A ball valve was installed in the lower part of the cone for periodic discharge of sediment. 


\section{Numerical simulation}

Hydrocyclone characteristics were determined by numerical simulation. The fields of water velocities and pressures were calculated by the finite element method using the k- $\varepsilon$ turbulence model [6]. It was assumed that a velocity profile typical of turbulent flow was formed at the entrance to the cyclone. The average water velocities at the inlet were taken 2,3 , and $4 \mathrm{~m} / \mathrm{s}$, which corresponded to volumetric flowrates $(3.1 \ldots 6.3) \cdot 10^{-3} \mathrm{~m}^{3} / \mathrm{s}$.

Figure 2 shows the calculated velocity field of water in a horizontal section passing through the center of the inlet snail. Speeds are shown by vectors and fill color.

It is seen that at the entrance to the main cylindrical section, a maximum water velocity of $5.277 \mathrm{~m} / \mathrm{s}$ is achieved, which is ensured by the geometry of the inlet section.

Figure 3 shows the velocity distributions in vertical cut drawn in the upper (left) and lower (right) parts of the hydrocyclone body. In the lower conical part, the velocities are significantly reduced, which creates conditions for the deposition of particles and prevents their entrainment.

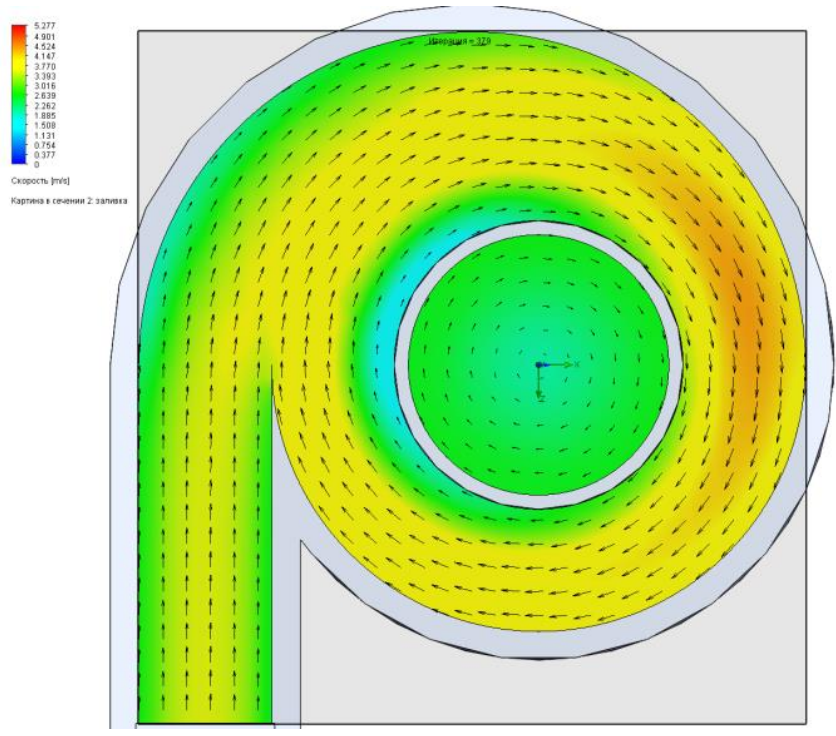

Figure 2 - The water velocity field in the horizontal cut at the inlet section of the hydrocyclone at $v_{l}=3 \mathrm{~m} / \mathrm{s}$

Knowing of the velocities distribution enables determination of the trajectories of solid particles (grains of sand) and calculation of the capture coefficient as the ratio of the number of particles deposited on the walls to the number of particles at the inlet.

For clarity, particle paths are shown with the num- ber of particles $n=50$. Figure 4 shows the trajectories of particles with a diameter of $50 \mu \mathrm{m}$ (left) and $40 \mu \mathrm{m}$ (right).

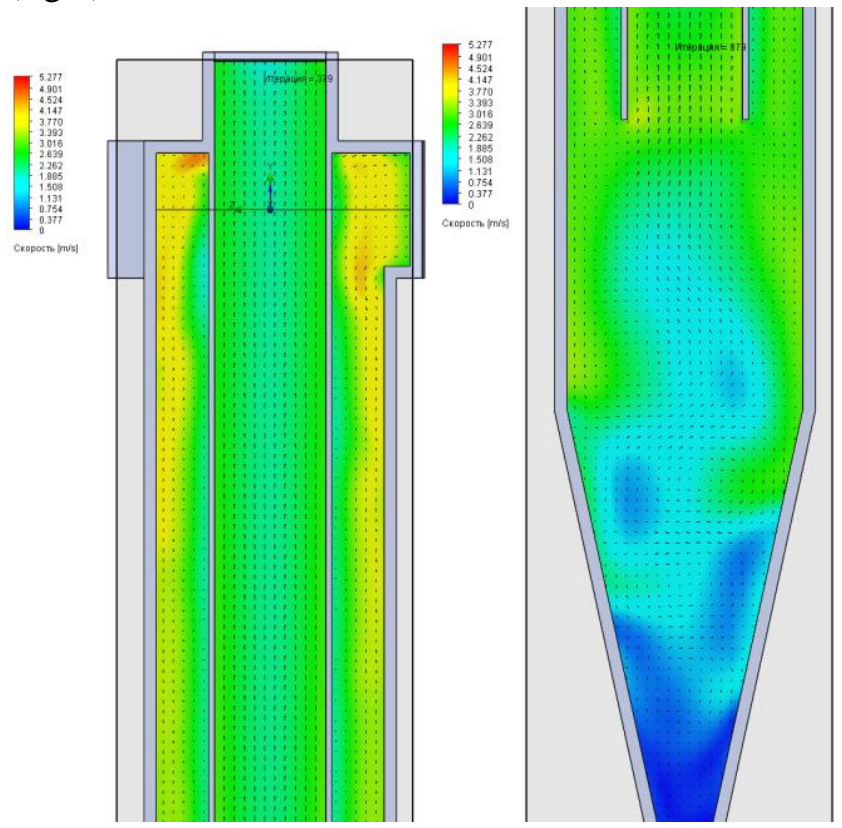

Figure 3 - The distribution of water velocities in vertical cut drawn through the axis of the hydrocyclone body

Figure 4 shows that at $d=50 \mu \mathrm{m}$ all the particles under study settle on the walls, while at $d=40 \mu \mathrm{m}$ some particles exit through the upper nozzle.

Subsequently, the hydrocyclone capture coefficient was calculated as

$$
K=\frac{n_{\text {capt. }}}{n},
$$

where $n_{\text {capt }}-$ the number of particles captured;

$n$ - the total number of particles used in the computer simulation.

Preliminary calculations showed that the number of particles "launched" into the model significantly affects the calculated value of the capture coefficient. With a large number of particles, the spread in values decreases. We can say that self-similarity in the number of particles sets in. However, the large number of particles drastically increases the calculation time.

In our calculations, a compromise number of particles $n=3000$ was accepted, which corresponded to the onset of self-similarity.

The values of the capture coefficient calculated according to (3) at various water inlet speeds are shown in Figure 5.

Figure 5 shows that increasing of water velocity results in the increasing of the capture coefficient. Ho- 
wever, further increase in speed can lead to the ablation speed being exceeded, and particles will not settle on the walls. The graph also shows that already at $v_{1}=3 \mathrm{~m} / \mathrm{s}$ almost all particles with a diameter of more than $50 \mu \mathrm{m}$ are captured by a hydrocyclone, which allows a fairly accurate estimate of the total sand content in water. However, poor particle capture of less than 50 microns is a disadvantage of the hydrocyclone.

Writing the Bernoulli equation for the inlet and outlet sections of the hydrocyclone, we obtain the formula for pressure loss:

$$
\Delta p=\rho g\left(z_{1}-z_{2}\right)+\left(p_{1}-p_{2}\right)+\frac{\rho}{2}\left(v_{1}^{2}-v_{1}^{2}\right)
$$

where $g-$ the acceleration of gravity, $\mathrm{m} / \mathrm{s}^{2}$;

$z_{1}$ and $z_{2}-$ geometric heights of the inlet and outlet sections, $\mathrm{m}$;

$p_{1}$ and $p_{2}-$ static pressure at the inlet and outlet of the hydrocyclone, $\mathrm{Pa}$;

$v_{1}$ and $v_{2}$-average consumption speeds at the inlet and outlet of the hydrocyclone, $\mathrm{m} / \mathrm{s}$.

The values of static pressures $p_{1}$ and $p_{2}$ were calculated in the course of the simulation. The pressure losses calculated according to (4) are presented in the graph (Figure 6).
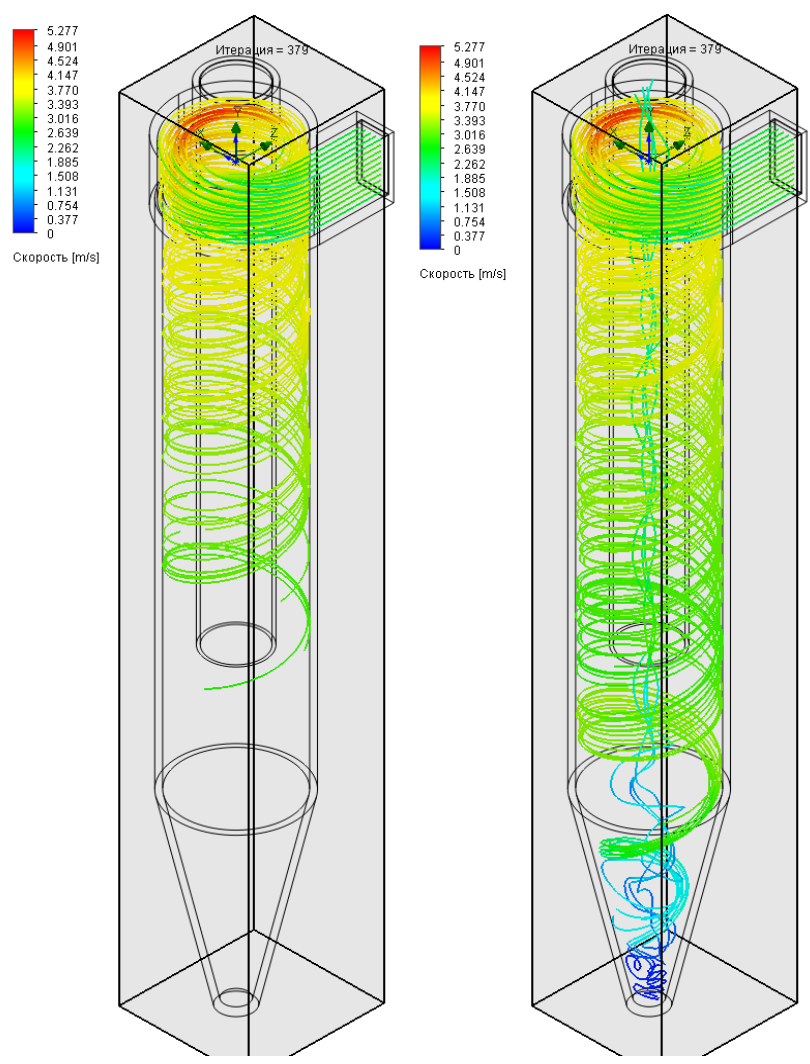

Figure 4 -Trajectories of sand particles with an initial number of particles $n=50$
From the results presented it can be seen that the pressure losses in the considered range does not exceed $14 \mathrm{kPa}$, which is acceptable for the selected equipment layout.

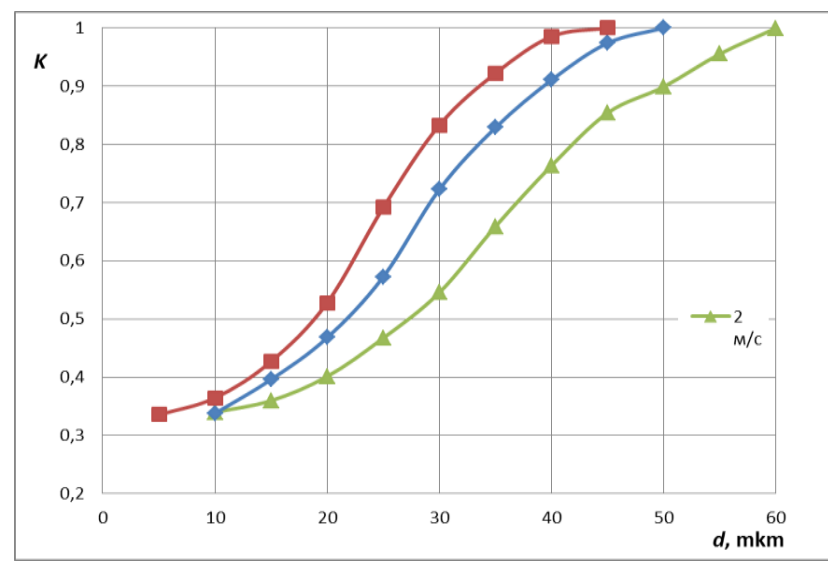

Figure 5 - The capture coefficient of sand particles as a function of particle diameter at different inlet water velocities

\section{Full-scale tests of the hydrocyclone}

During testing, once a day, sand was drained from the hopper (Figure 7). The precipitate was dried in the sun, and the mass of sand was determined by weighing. It was found that during the month the daily mass of trapped sand did not exceed $0.5 \mathrm{~kg}$.

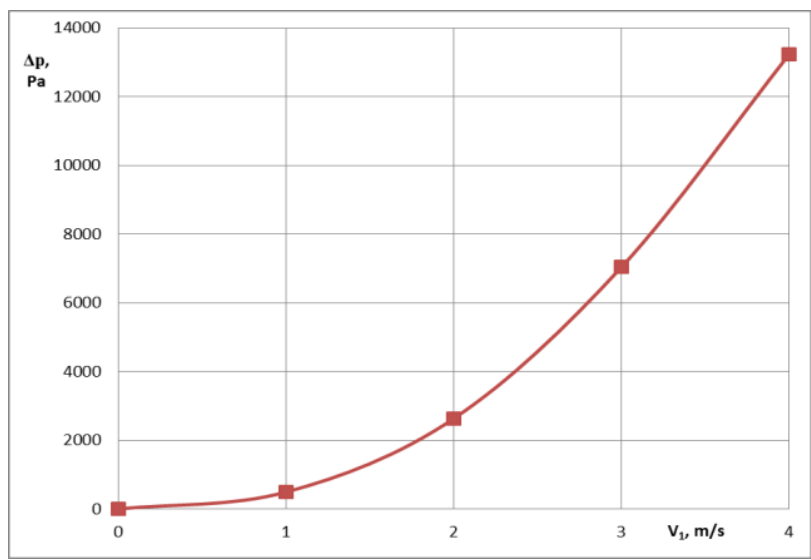

Figure 6 - Pressure losses in hydrocyclone at various inlet water speeds

Thise measurements made it possible to choose a sand filter for continuous operation, which ensured the reliable operation of the desalination system using the principle of reverse osmosis (Figure 8).

\section{Conclusions}

Numerical modeling made it possible with reasonable accuracy to estimate the sand capture coeffi- 
cient by an experimental hydrocyclone. During the tests, the mass of sand entering the pipeline per day was determined.

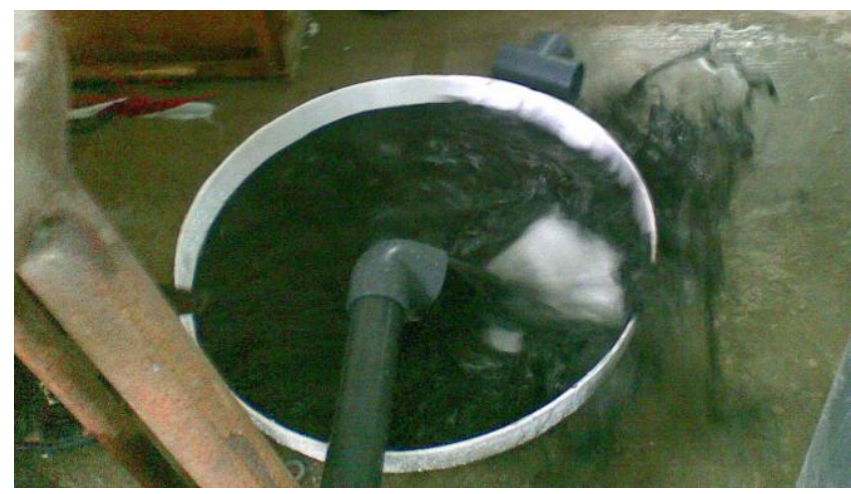

Figure 7 - The selection of sand captured per day

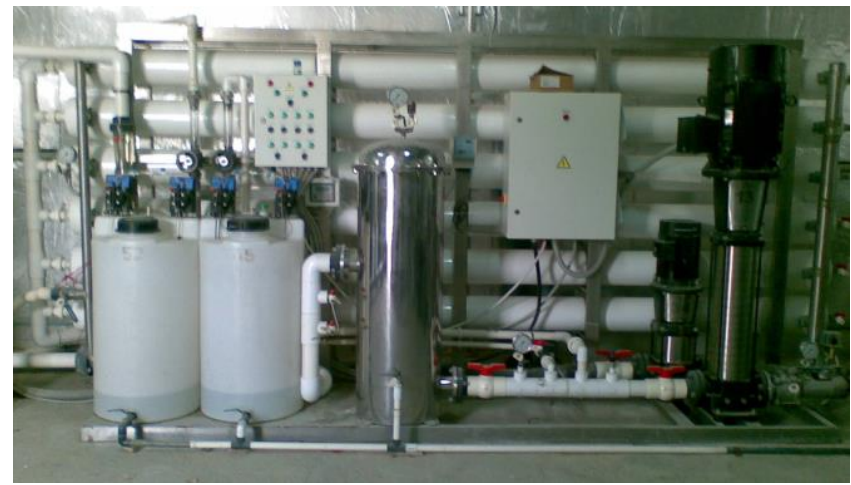

Figure 8-Desalination plant using the principle of reverse osmosis

The hydrocyclone reliably captures sand particles of 50 microns or more. At the same time, a significant part of particles less than 50 microns is not captured by the hydrocyclone, which is why a sand filter was chosen for industrial use.
In the future, it is advisable to use a serial connection of a hydrocyclone and a sand filter, but such a solution requires additional technical and economic calculation.

\section{References}

1. Geography of the United Arab Emirates (UAE). http://www.gecont.ru/articles/geo/oae.htm (Date accessed 08/28/2019)

2. Zapolsky, A. K. (2005) Water Supply, Drainage and Water Quality: A Textbook. K.: Higher School, 671. (in Russian).

3. Naidenko, V. V., Kulakova, A. P., Sherenkov, I. A. (1984) Optimization of natural and waste water treatment processes. M.: Stroyizdat, 152. (in Russian).

4. Ternovsky, I. G., Kutepov, A. M. (1994) Hydrocyclone. M .: Nauka, 350. (in Russian).

5. Basharov, M. M., Sergeeva, O. A. (2012) The device and calculation of hydrocyclones: a training manual. Ed. A. G. Laptev. Kazan: Westfalika, 92. (in Russian).

6. Alyamovsky, A. A. (2012) Solid Works Simulation. How to solve practical problems. SPb.: $B H V$ Petersburg, 448. (in Russian).

7. Surkov, S. V., Tsabiev, O. N. (2004) Calculation of the movement of dust particles using mathematical models of secondary flows. Tr. Odessa Polytechnic University, 2 (22), 184-188. (in Russian).

Received 03 June 2019

Approved 02 July 2019

Available in Internet 05 September 2019

\title{
Чисельне моделювання гідроциклону в системі технічного водопостачання в умовах ОАE
}

\author{
С. В. Сурков ${ }^{1 凶}$ Хуссам Ганем², В. П. Кравченко ${ }^{3}$ \\ ${ }_{1,2,3}$ Одеський національний політехнічний університет, пр-т Шевченка, 1, м. Одеса, 65044, Україна \\ $\triangle$ e-mail:: ${ }^{1}$ ssv@opu.ua \\ ORCID: ${ }^{1}$ https://orcid.org/0000-0002-3112-3041; ${ }^{2}$ https://orcid.org/0000-0002-2416-198X; \\ ${ }^{3}$ https://orcid.org/0000-0002-7557-3327
}

Стаття присвячена виріменню практичної проблеми: вибору обладнання для попередньої обробки солоної води, яка живить установку для знесолення. Попередній етап опріснення - очищення води від частинок піску, що може значно знизити продуктивність $і$ навіть пошкодити установку для опріснення, що знаходиться на наступному етапі. Для попередньої обробки використовують відстійники, гідрочиклони, піщані фільтри тощо. Основні розміри гідроциклонів стандартних кон- 
струкиій розраховуються на основі відомих рекомендацій. Сучасні системи комп'ютерного моделювання дозволяють створювати тривимірні моделі досліджуваного апарату, а потім обчислювати поля швидкості та тиску в них. Необхідно було оцінити кількість піску, щэо міститься у живильній воді. Для вирішення иієё проблеми був розроблений і виготовлений експериментальний гідроииклон. Гідрочиклон був чисельно модельований і очінювали коефічієнт захоплення піску в різних робочих умовах. Встановлено, що експериментальний гідроииклон надійно захоплює зерна піску розміром 50 мкм і вище. Експериментально було визначено середньодобову масу піску, що вловлюється. Числове моделювання дозволило з розумною точністю оцінити коефіцієнт захоплення піску експериментальним гідрочиклоном. Під час випробувань визначали масу піску, що надходить у трубопровід за добу. Гідроииклон надійно захоплює частинки піску 50 мкм і більще. У той же час значна частина частинок менше 50 мкм не захоплюється гідрочиклоном, через що пісочний фільтр був обраний для промислового використання. Надалі доиільно використовувати послідовне з'єднання гідроииклону та піщаного фільтру, але таке рімення потребує додаткових техніко-економічних розрахунків. Зроблено висновок, що в даному випадку для попереднього очищення води доцільно використовувати піщаний фільтр.

Ключові слова: Чисельне моделювання; Гідрочиклон; Система технічного водопостачання; Піщані фільтри; Попередне очищення води

\section{Література}

1. География Объединенных Арабских Эмиратов (OАЭ) / Электронный pecypc http://www.gecont.ru/ articles/geo/oae.htm (Дата обращения 28.08.2019)

2. Запольський А. К. Водопостачання, водовідведення та якість води: Підручник. - К.: Вища шк., 2005. $-671 \mathrm{c}$.

3. Найденко В. В., Кулакова А. П., Шеренков И. А. Оптимизация процессов очистки природных и сточных вод. - М.: Стройиздат, 1984. - 152c.

4. Терновский И. Г., Кутепов А. М. Гидроцикло- нирование. - М.: Наука, 1994. - 350 с.: ил.

5. Башаров М. М., Сергеева О. А. Устройство и расчет гидроциклонов: учебное пособие. Под ред. А. Г. Лаптева. - Казань: Вестфалика, 2012. - 92 с. 6. Алямовский А. А. SolidWorks Simulation. Как решать практические задачи. - СПб.: БХВ-Петербург, 2012. - $448 \mathrm{c}$.

7. Сурков С. В., Цабиев О. Н. Расчет движения пылевых частиц с использованием математических моделей вторичных течений. - Тр. Одес. политехн. ун-та, 2004, вып. 2(22). с. 184-188.

Отримана в редакції 03.06.2019, прийнята до друку 02.07.2019 